PEMBELAJAR: Jurnal Ilmu Pendidikan, Keguruan, dan Pembelajaran

Volume 2 Nomor 1 April 2018 hal 12-24

e-ISSN: 2549-9114 dan p-ISSN: 2549-9203

(Received: Februari-2018; Reviewed: Maret-2018; Published: April 2018)

\title{
Pengaruh Model Pembelajaran Kooperatif Terhadap Motivasi Dan Hasil Belajar Siswa Pada Materi Sistem Koloid SMAN 4 Bantimurung Maros
}

\author{
Muhlis \\ Pendidikan Kimia, Program Pascasarjana Universitas Negeri Makassar \\ Corespondensi e-mail: muhlis1971@yahoo.co.id
}

\begin{abstract}
Abstrak. Penelitian ini bertujuan untuk mengetahui (1) pengaruh model pembelajaran kooperatif terhadap motivasi belajar (2) pengaruh model pembelajaran kooperatif terhadap hasil belajar (3) hubungan antara motivasi dengan hasil belajar yang dibelajarkan dengan menggunakan model pemebealajaran kooperatif. Penelitian ini merupakan quasi eksperimen. Populasi dalam penelitian ini adalah siswa kelas XI IPA SMAN 4 Bantimurung-Maros tahun ajaran 2016/2017 sebanyak 5 kelas yang berjumlah 170 siswa. Sampel penelitian ini dipilih melalui random sampling terdiri atas 2 kelas yaitu kelas XI IPA 2 yang dibelajarkan dengan menggunakan model pembelajaran kooperatif tipe Jigsaw dengan jumlah siswa sebanyak 35 dan kelas XI IPA 3 dibelajarkan dengan menggunakan model pembelajaran kooperatif tipe STAD dengan jumlah siswa sebanyak 35. Instrumen dalam penelitian ini yaitu angket motivasi belajar digunakan untuk mengetahui motivasi belajar siswa pada penerapan model pembelajaran kooperatif dan butir tes hasil belajar pada penerapan model pembelajaran kooperatif. Pengujian hipotesis dilakukan dengan bantuan program SPSS 20.00 for Windows dengan menggunakan analisis Independent Samples Test. Hasil analisis statistik deskriptif menyatakan bahwa nilai rata-rata motivasi belajar yang dibelajarkan dengan model pemebelajaran kooperatif tipe Jigsaw dan STAD yaitu 86,63 dengan katergori sangat baik dan 84,97 dengan kategori baik, dan rata-rata nilai N-Gain hasil belajar pada model pembelajaran kooperatif tipe Jigsaw dan STAD yaitu 0,63 dan 0,35 dengan kategori sedang. Hasil analisis statistik inferensial diperoleh nilai signifikansi $0,001<0,05$ untuk motivasi belajar maka $\mathrm{H}_{0}$ ditolak dan $\mathrm{H}_{1}$ diterima artinya ada pengaruh model pembelajaran kooperatif terhadap motivasi belajar, nilai signifikansi $0,000<0,05$ untuk hasil belajar maka $\mathrm{H}_{0}$ ditolak dan $\mathrm{H}_{1}$ diterima artinya ada pengaruh model pembelajaran kooperatif terhadap hasil belajar, dan nilai signifikansi $0,010<0,05$ untuk korelasi maka $\mathrm{H} 0$ ditolak dan $\mathrm{H}_{1}$ diterima artinya ada hubungan secara signifikansi antara motivasi dengan hasil belajar, nilai koefisien korelasi sebesar 0,306 dengan kategori lemah, arah hubungannya adalah positif karena nilai korelasi positif. Berdasarkan hasil analisis statistik inferensial maka dapat disimpulkan bahwa (1) ada pengaruh model pembelajaran kooperatif terhadap motivasi belajar (2) ada pengaruh model pembelajaran kooperatif terhadap hasil belajar (3) ada hubungan antara motivasi dengan hasil belajar pada materi sistem koloid dengan penerapan model pebelajaran kooperatif.
\end{abstract}

Kata kunci: Kooperatif, Jigsaw, STAD, Motivasi belajar, Hasil belajar

(C2018 -Pembelajar Universitas Negeri Makassar. Ini adalah artikel dengan akses terbuka dibawah licenci CC BY-NC-4.0 (https://creativecommons.org/licenses/by-nc/4.0/ ). 


\section{PENDAHULUAN}

Pengembangan potensi guru melalui kegiatan pembelajaran, telah diamanatkan dalam Undang-Undang No. 20 tahun 2003 melalui sistem Pendidikan Nasional yang menyebutkan bahwa tujuan Pendidikan Nasional adalah "Usaha sadar dan terencana untuk mewujudkan suasana belajar dan proses pembelajaran agar siswa secara aktif mengembangkan potensi dirinya untuk memiliki kekuatan spiritual keagamaan, pengendalian diri, kepribadian, kecerdasan, akhlak mulia, serta keterampilan yang diperlukan dirinya, masyarakat, bangsa dan negara "Untuk mencapai tujuan pembelajaran, proses pembelajaran harus lebih menekankan pada bagaimana upaya untuk mendorong dan menfasilitasi siswa dalam proses pembelajaran, agar siswa lebih berperan aktif dalam mengkonstruksikan pengetahuan bagi dirinya sendiri sehingga tidak merasa jenuh dalam menerima dan mengikuti pembelajaran. Kegiatan pembelajaran di SMA pada saat ini, khususnya mata pelajaran kimia umumnya belum berjalan sebagaimana yang diharapkan yaitu perlu interaksi-interaksi sosial antara guru dan sesama siswa serta lingkungannya. Guru umumnya menggunakan metode ceramah dalam menyajikan materi pelajaran, masih cenderung mendominasi kegiatan pembelajaran yang berpusat pada guru (teacher centred) maka pengetahuan siswa dalam proses pembelajaran belum maksimal. Hal ini berdampak pada motivasi dan hasil belajar siswa yang rendah. Untuk meningkatkan motivasi dan hasil belajar siswa, proses pembelajaran diperlukan keterlibatkan siswa lebih aktif dalam proses pembelajaran, yaitu memilih model pembelajaran yang melibatkan siswa secara aktif.Pembelajaran model kooperatif adalah pembelajaran siswa aktif yang lebih menekankan pada pengembangan kemampuan kognitif siswa dimbangi dengan perkembangan pribadi secara utuh melalui kemampuan interpersonal (Sanjaya, 2013). Berdasarkan observasi awal di SMAN 4 Bantimurung melalui wawancara dengan guru kimia, diperoleh informasi motivasi belajar yang kurang dan hasil belajar yang belum maksimal pada mata pelajaran kimia khususnya materi sistem koloid. Kurangnya motivasi dan hasil belajar siswa pada materi sistem koloid karena pada proses pembelajaran siswa kurang aktif, strategi guru manyampaikan materi ajar menggunakan model pembelajaran langsung yang dipadukan dengan metode ceramah. Pada proses pembelajaran langsung keakifan siswa bersikap pasif sehingga motivasi siswa menjadi rendah. Hasil penilaian pada materi sistem koloid pada tahun pelajaran 2015/2016 umumnya siswa memperoleh nilai hasil belajar di bawah Kriteria Ketuntasan Minimum ( KKM ) yang telah ditetapkan yaitu 75 pencapainnya $50 \%$. Untuk mengatasi hal tersebut diperlukan upaya guru untuk mengubah strategi dalam kegiatan pembelajaran yang selama ini digunakan pada materi sistem koloid yaitu model pembelajaran yang berpusat pada guru menjadi siswa aktif (student centred) dengan memilih model pembelajaran kooperatif atau berkelompok. Pembelajaran secara kooperatif siswa akan termotivasi dalam kegiatan pembelajaran, karena berinteraksi antara sesama siswa dan dengan guru.Pembelajaran kooperatif lebih menekankan siswa aktif, akan memudahkan siswa memahami materi pelajaran seperti materi sistem koloid yang tidak banyak melibatkan perhitungan seperti materi pelajaran kimia yang ada pada kelas XI IPA. Siswa aktif pada kegiatan pembelajaran akan meningkatkan hasil belajar seperti materi sistem koloid yang mencakup konsep-konsep kongkrit misalnya fenomenafenomena alam yang terjadi dalam kehidupan sehari-hari. Model pembelajaran kooperatif terdiri dari beberapa tipe, diantaranya adalah pembelajaran kooperatif tipe Jigsaw dan tipe Student Teams Achievement Division (STAD). Penerapan model pembelajaran kooperatif tipe Jigsaw dan model pembelajaran kooperatif tipe STAD oleh guru dalam menyampaikan materi pelajaran akan memberikan dorongan dalam diri siswa untuk aktif dalam proses pembelajaran. Motivasi belajar ada dua aspek yaitu : motivasi ekstrinsik, yaitu melakukan sesuatu untuk mendapatkan sesuatu yang lain (cara untuk mencapai tujuan) dan motivasi intrinsik, yaitu motivasi internal untuk melakukan sesuatu demi sesuatu itu sendiri (Sardiman, 2014). Motivasi intrinsik lebih kuat dari motivasi ekstrinsik oleh karena itu pembelajaran harus berusaha menimbulkan motif intrinsik dengan menumbuhkembangkan minat siswa terhadap materi ajar (Hamzah, 2016). Penerapan model pembelajaran kooperatif tipe Jigsaw dan model pembelajaran kooperatif tipe STAD, guru hendaknya menyesuaikan bahan ajar yang relevan akan membantu dan mengarahkan kesiapan siswa untuk menerima materi pembelajaran sesuai model yang diterapkan 
dengan karakteristik siswa dalam pembelajaran. Proses pembelajaran diupayakan pada kegiatan belajar yang bermakna, melalui penerapan model pembelajaran kooperatif tipe Jigsaw dan model pembelajaran kooperatif tipe STAD siswa akan lebih aktif dalam memahami materi ajar, dan membantu siswa dalam menyelesaikan tugas yang diberikan akan memperoleh nilai hasil belajar yang maksimal. Fadlyani (2014), melaporkan bahwa penerapan pembelajaran kooperatif tipe Jigsaw dapat meningkatkan hasil belajar siswa lebih tinggi dibandingkan hasil belajar siswa secara konvensional. Selanjutnya Erikson ( 2015 ) melaporkan bahwa siswa termotivasi tinggi dengan pembelajaran koperatif tipe Jigsaw daripada pembelajaran secara langsung. Demikian halnya Suprapto ( 2015 ) juga melaporkan bahwa penerapan model pembelajaran kooperatif tipe STAD pada kemampuan pemecahan masalah terlihat peningkatan nilai pretes yaitu 9,143 menjadi 12 , 743 pada posttest.

\subsection{Model Pembelajaran Kooperatif}

Pembelajaran kooperatif (Cooperative Learning) merupakan bentuk pembelajaran dengan cara siswa belajar dan bekerja dalam kelompok-kelompok kecil secara kalaboratif yang anggotanya terdiri dari empat sampai enam orang dengan struktur kelompok yang bersifat heterogen (Rusman, 2010). Pembelajaran kooperatif adalah pendekatan pembelajaran yang berfokus pada penggunaan kelompok kecil siswa untuk bekerja sama dalam memaksimalkan kondisi belajar untuk mencapai tujuan belajar (Nurhadi, 2004 ). Secara umum pembelajaran kooperatif adalah model pembelajaran dengan menggunakan sistem pengelompokan atau tim kecil, yaitu antara empat sampai enam orang yang mempunyai latar belakang kemampuan berbeda. Dalam menyelesaikan tugas kelompoknya setiap siswa harus saling bekerja sama dan saling membantu untuk memahami materi pelajaran. Pembelajaran kooperatif disusun dalam sebuah usaha untuk meningkatkan partisipasi siswa, memfasilitasi siswa dengan pengalaman sikap kepemimpinan dan membuat keputusan dalam kelompok, serta memberikan kesempatan pada siswa yang berbeda latar belakangnya (Trianto, 2010).

\subsection{Model Pembelajaran Kooperatif Tipe Jigsaw}

Pembelajaran kooperatif tipe Jigsaw ini dikembangkan oleh Elliot Aronson's. Kooperatif tipe Jigsaw ini didesain untuk meningkatkan rasa tanggungjawab siswa terhadap pembelajarannya sendiri dan juga pembelajaran orang lain. Model mengajar Jigsaw dikembangkan oleh Elliot Aronson's sebagai model Cooperative learning. Metode ini dapat digunakan dalam pengajaran membaca, menulis, mendengarkan, ataupun berbicara, dalam model ini, guru memperhatikan skemata atau latar belakang pengalaman siswa dan membantu siswa mengaktifkan skemata ini agar bahan pelajaran menjadi lebih bermakna. Selain itu, siswa bekerja sama dengan sesama siswa dalam suasana gotong royong dan mempunyai banyak kesempatan untuk mengolah informasi dan meningkatkan keterampilan berkomunikasi. Siswa tidak hanya mempelajari materi yang diberikan, tetapi mereka juga harus siap memberikan dan mengajarkan materi tersebut pada anggota kelompoknya. dengan demikian siswa saling tergantung satu dengan yang lain dan harus bekerjasama secara kooperatif untuk mempelajari materi yang ditugaskan (Lie, 2004). Pada pembelajaran model kooperatif tipe Jigsaw, terdapat kelompok asal dan kelompok ahli. Kelompok asal yaitu kelompok induk siswa yang beranggotakan siswa dengan kemampuan, asal, dan latar belakang keluarga yang beragam. Kelompok asal merupakan gabungan dari beberapa ahli. kelompok ahli yaitu kelompok siswa yang terdiri dari anggota kelompok asal yang berbeda yang ditugaskan untuk mempelajari dan mendalami topik tertentu dan menyelesaikan tugas-tugas yang berhubungan dengan topiknya untuk kemudian dijelaskan kapada anggota kelompok asal (Suprijono, 2013).

\subsection{Model Pembelajaran Kooperatif Tipe STAD}

Model pembelajaran kooperatif tipe Student Teams Achievement Divisions (STAD) merupakan salah satu pendekatan dalam pembelajaran kooperatif yang paling sederhana, yang dikembangkan oleh Robert Slavin di Universitas John Hopkin, dan merupakan sebuah pendekatan yang baik untuk guru yang baru menerapkan model pembelajaran kooperatif di kelas. Pembelajaran kooperatif tipe STAD dibagi menjadi lima komponen utama yaitu: presentasi kelas (class presentations), belajar kelompok 
(teams), kuis (quizzes), peningkatan skor individu (individual improvement scores), dan penghargaan kelompok (team recognition) ( Slavin, 2010 ). Pembelajaran kooperatif memiliki dampak yang positif terhadap siswa yang rendah hasil belajarnya, karena siswa yang rendah hasil belajarnya dapat meningkatkan minat, hasil belajar, dan penyimpanan materi pelajaran yang lebih lama. Terdapat enam langkah utama atau tahapan di dalam pelajaran yang menggunakan pembelajaran kooperatif tipe STAD (Trianto, 2007). Langkah-langkahnya adalah sebagai berikut: (1) menyampaikan tujuan dan memotivasi siswa, (2) menyajikan informasi, (3) mengorganisasikan siswa kedalam kelompok kooperatif, (4) membimbing kelompok bekerja dan belajar, (5) evaluasi, dan (6) memberikan penghargaan.

\subsection{Motivasi Belajar}

Motivasi berasal dari kata motif yang diartikan sebagai kekuatan yang terdapat dalam diri individu, yang menyebabkan individu tersebut bertindak atau berbuat motif tidak dapat diartikan secara langsung tetapi dapat diinterprestasikan dalam tingkah lakunya, berupa rangsangan, dorongan, atau pembangkit tenaga munculnya suatu tingkah laku tertentu (Rukminto, 1994). Motivasi belajar adalah merupakan faktor psikis yang bersifat non, intektual (Sardiman, 2014). Peranannya yang khas adalah dalam hal penumbuhan gairah, merasa senang dan semangat untuk belajar siswa yang memiliki motivasi kuat, akan mempunyai banyak energy untuk melakukan kegiatan belajar. Secara umum motivasi dibedakan atas dua jenis, yaitu motivasi instrinsik dan motivasi ekstrinsik. Menurut Gunarsa (2004) yaitu: (1) motivasi instrinsik merupakan dorongan atau kehendak yang kuat berasal dalam diri seseorang. Semakin kuat motivasi instrinsik yang dimiliki oleh seseorang, semakin besar kemungkinan memperlihatkan tingkah laku yang kuat untuk mencapai tujuan, dan (2) motivasi ekstrinsik adalah dorongan segala sesuatu yang diperolah melalui pengamatan sendiri, ataupun melalui saran, anjuran, atau dorongan dari orang lain. Hakikat motivasi belajar adalah dorongan internal dan eksternal pada siswa yang sedang belajar untuk mengadakan perubahan tingkah laku, pada umumnya dengan beberapa indicator atau unsur yang mendukung. Menurut Uno (2016) motivasi belajar mempunyai peranan besar dalam keberhasilan seseorang dalam belajar indikator motivasi belajar diklasifikasikan sebagai berikut : adanya hasrat dan keinginan berhasil, adanya dorongan dan kebutuhan dalam belajar, adanya harapan dan cita-cita masa depan, adanya penghargaan dalam belajar, adanya kegiatan yang menarik dalam belajar, adanya lingkungan belajar yang kondusif, sehingga memungkinkan seorang siswa dapat belajar dengan baik. Berdasarkan beberapa pendapat ahli yang telah dikemukakan diatas, maka indikator motivasi belajar yang akan digunakan dalaam penelitian ini adalah: adanya hasrat dan keinginan berhasil, adanya dorongan dan kebutuhan dalam belajar, adanya harapan dan cita-cita masa depan, adanya penghargaan dalam belajar, adanya kegiatan yang menarik dalam belajar, adanya lingkungan belajar yang kondusif dan adanya kerjasam dan perhatian.

\subsection{Hasil Belajar}

Hasil belajar adalah akibat dari aktivitas yang dapat diketahui perubahannya dalam pengetahuan, pemahaman, keterampilan, dan nilai sikap melalui ujian tes atau ujian (Sudjana, 1996). Benyamin Bloom membagi hasil belajar menjadi tiga ranah (Anni, 2004) yaitu : ranah kognitif, ranah psikomotor, dan ranah afektif. Hasil belajar telah tercapai apabila telah terpenuhi dua indicator berikut: daya serap terhadap bahan pengajaran yang diajaran mencapai prestasi tinggi, baik secara individual maupun kelompok dan perilaku yang digariskan dalam tujuan pengajaran/instruksional khusus telah dicapai oleh siswa baik secara individual maupun kelompok (Susanto, 2013). Berdasarkan beberapa pendapat yang telah dikemukakan mengenai pengertian hasil belajar, penelitian ini menilai dari hasil belajar kognitif dengan menggunakan indikator : pengetahuan, pemahaman, penerapan, analisis, sinstesis dan evaluasi.

\subsection{Tinjauan Materi Sistem Koloid}

Salah satu materi yang dipelajari dalam pembelajaran kimia di SMA dan MA adalah sistem koloid. Berdasarkan standar isi yang tercakup pada kompetensi dasar silabus Kurikulum Tingkat Satuan Pendidikan (KTSP) tahun 2006 disebutkan bahwa materi sistem koloid yang diajarkan di Sekolah Menengah Atas (SMA) terdiri dari dua Kompetensi Dasar yang meliputi kompetensi dasar 5.1 yaitu mengelompokkan sifat-sifat koloid dan penerapannya dalam kehidupan sehari-hari, dan kompetensi dasar 5.2 yaitu membuat berbagai 
koloid dengan bahan-bahan yang ada di sekitarnya. Kompetensi dasar 5.1 membahas tiga sub materi yaitu: (1) sistem koloid; (2) sifat-sifat koloid; dan (3) jenis-jenis koloid. Kompetensi dasar 5.2 membahas tentang pembuatan koloid dengan cara kondensasi dan dispersi (Depdiknas, 2006).

\subsection{Model Pembelajaran Kooperatif \\ Terhadap Motivasi Belajar \\ Proses pembelajaran kooperatif tipe} Jigsaw dan STAD siswa akan aktif karena pembelajaran dipusatkan pada siswa (student centre) pada pebelajaran kooperatif guru bertindak sebagai motivator. Keaktifan siswa dalam proses pembelajaran akan mendorong siswa untuk lebih memahami materi pelajaran. Tanggung jawab siswa sebagai tutor sebaya dalam proses pembeajaran kooperatif tipe Jigsaw dan STAD akan muncul dari dalam diri siswa dorongan untuk mancapai tujuan yang telah ditetapkan.

\subsection{Model Pembelajaran Kooperatif \\ Terhadap Hasil Belajar}

Model pembelajaran kooperatif tipe Jigsaw dan Student Teams Achievement Divisions (STAD) merupakan model pembelajaran siswa belajar dalam kelompok kecil yang terdiri dari empat sampai enam siswa yang heterongen. Pembelajaran kooperatif tipe Jigsaw dan STAD siswa belajar secara aktif dalam kelompoknya untuk menyelesaikan tugas baik secara individu maupun kelompok.Proses pembelajaran berdasarkan tugas yang diberikan secara berkelompok untuk mempelajari dan mendiskusikan siswa akan mencari jawaban atau menyelesaikan tugas yang diberikan oleh guru. Materi pelajaran yang diberikan setiap kelompok harus saling membantu dalam memahami materi pelajaran yang diberikan atau ditugaskan dengan kemampuan siswa yang saling membelajarkan akan berpengaruh terhadap kemampuan penguasaan berpikirnya. Sebagai tutor sebaya dalam kelompoknya akan mengakibatkan perubahan pada siswa yaitu kemampuan untuk memahami materi yang merupakan tanggung jawabnya, kemampuan yang dimiliki siswa dalam pembelajaran dapat meningkatkan hasil belajarnya.

\subsection{Hubungan Motivasi Dengan Hasil Belajar} Motivasi belajar dorongan oleh keinginan siswa untuk memahami materi pelajaran, dorongan ini dapat timbul dari dalam maupun dari luar diri siswa. Dorongan dari dalam itu bisa berupa keinginan untuk mengetahui dan memahami materi pelajaran yang sedang dibelajarkan seperti kemauan siswa itu sendiri untuk memahami pelajaran. Keinginan siswa belajar pada materi yang berupa konsepkensep atau fenomena-fenomena yang terjadi di lingkungan siswa seperti materi sistem koloid memberikan dorongan dalam diri siswa untuk lebih mudah memahami.Siswa akan memperoleh hasil belajar yang baik apabila pembelajaran yang dilakukan adanya kemauan siswa yang kuat untuk berhasil memahami pelajaran, adanya dorongan dari dalam diri siswa akan membuat lebih mudah memahami materi pelajaran. Dorongan yang timbul dari dalam diri siswa maupun dari luar mampu mempengaruhi daya ingat siswa dalam menyelesaikan tugas-tugas dalam pembelajaran sehingga akan meningkatkan hasil belajarnya.

Berdasarkan uraian dari kajian pustaka dan kerangka pikir yang telah dikemukakan sebelumnya, maka dirumuskan hipotesis sebagai berikut: (1) ada pengaruh model pembelajaran kooperatif terhadap motivasi belajar siswa pada materi sistem koloid. (2) ada pengaruh model pembelajaran kooperatif terhadap hasil belajar siswa pada materi sistem koloid. (3) ada hubungan antara motivasi dengan hasil belajar siswa pada materi sistem koloid penerapan model pembelajaran kooperatif.

\section{METODE}

Jenis penelitian ini adalah penelitian eksperimen semu (quasi eksperimen) dengan menggunakan perlakuan pada obyek penelitian dengan melibatkan dua kelas yaitu Kelas XI IPA 2 dibelajarkan dengan model pembelajaran kooperatif tipe Jigsaw dan kelas XI IPA 3 dibelajarkan dengan model pembelajaran kooperatif tipe Student Team Achievement Division (STAD). Desain penelitian ini adalah Pretest-Postest Control Group Design (Sugiyono, 2013) yang dapat dilihat pada Tabel 1

Tabel 1. Desain Penelitian

\begin{tabular}{ccc}
\hline Pre test & Perlakuan & Post test \\
\hline $\mathrm{O}_{1}$ & $\mathrm{X}_{1}$ & $\mathrm{O}_{2}$ \\
\hline $\mathrm{O}_{3}$ & $\mathrm{X}_{2}$ & $\mathrm{O}_{4}$ \\
\hline
\end{tabular}

Keterangan :

$\mathrm{X}_{1} \quad$ : Penerapan model pembelajaran kooperatif tipe Jigsaw

$\mathrm{X}_{2} \quad$ : Penerapan model pembelajaran kooperatif tipe STAD 
$\mathrm{O}_{1} \quad$ : Motivasi dan hasil belajar sebelum penerapan model pembelajaran kooperatif tipe Jigsaw

$\mathrm{O}_{2} \quad$ : Motivasi dan hasil belajar sesudah penerapan model pembelajaran kooperatif tipe Jigsaw

$\mathrm{O}_{3} \quad$ : Motivasi dan hasil belajar sebelum penerapan model pembelajaran

kooperatif tipe STAD

$\mathrm{O}_{4} \quad$ : Motivasi dan hasil belajar sesudah penerapan model pembelajaran kooperatif tipe STAD

Variabel dalam penelitian ada dua jenis yaitu variabel bebas ( variabel independen) yaitu pembelajaran kooperatif yang terdiri dari model pemebelajaran kooperatif tipe Jigsaw dan model pembelajaran kooperatif tipe STAD dan variabel terikat (variabel dependent )yaitu motivasi belajar dan hasil belajar pada materi sistem koloid. Variabel penelitian didefenisikan secara operasional sebagai berikut: (1) model pembelajaran kooperatif tipe Jigsaw adalah kegiatan pembelajaran secara berkelompok yang meliputi beberapa tahap yaitu menyampaikan tujuan pembelajaran, membentuk kelompok asal, membentuk kelompok ahli, berdiskusi dalam kelompok ahli, presentasi tiap kelompok, menyimpulkan hasil diskusi, dan evaluasi. (2) model pembelajaran kooperatif tipe STAD adalah kegiatan pembelajaran secara berkelompok yang meliputi beberapa tahap yaitu menyampaiakan tujuan pembelajaran , menbentuk kelompok, menyajikan materi pelajaran, mengerjakan tugas kelompok, presentasi tiap kelompok, menyimpulkan hasil diskusi, dan evaluasi. (3) motivasi belajar adalah dorongan atau keinginan siswa untuk memenuhi kebutuhan dari dalam dirinya ataupun dari luar untuk mencapai tujuan pembelajaran. Motivasi siswa diukur melalui indikator yang ditunjukkan siswa dalam bentuk : hasrat dan keinginan berhasil, dorongan dan kebutuhan dalam belajar, harapan dan cita-cita masa depan, penghargaan dalam belajar, kegiatan yang menarik dalam belajar, lingkungan belajar yang kondusif, dan kerjasama dan perhatian. (4) hasil belajar adalah hasil pengukuran yang dijadikan dasar pada kemampuan kognitif dengan menggunakan indikator : pengetahuan, pemahaman, penerapan, analisis, sinstesis dan evaluasi.

Populasi dalam penelitian ini adalah seluruh kelas XI IPA SMAN 4 Bantimurung Kabupaten Maros tahun ajaran 2016/2017 yang terdiri lima kelas dengan jumlah 170 siswa yang penyebarannya secara acak tanpa dikelompokkan berdasarkan peringkat. Sampel dalam penelitian ini terdiri atas dua kelas eksprimen yang dipilih secara random sampling, yaitu pengambilan sampel dari populasi secara acak kelas yang mempunyai karakteristik yang sama. Kelas ekperimen pertama yaitu kelas XI IPA 2 yang dibelajarkan dengan menggunakan model pembelajaran kooperatif tipe Jigsaw jumlah siswa sebanyak 35 dan kelas eksperimen kedua yaitu kelas XI IPA 3 dibelajarkan dengan menggunakan model pembelajaran kooperatif tipe STAD dengan jumlah siswa sebanyak 35 . Penelitian ini dilakukan di semester genap tahun pelajaran 2016/2017 yang bertempat di SMAN 4 Bantimurung, Kecamatan Bantimurung Kabupaten Maros Propinsi Sulawesi Selatan. Penelitian ini dilaksanakan dengan lima kali pertemuan, tiga kali pertemuan tatap muka dan dua kali pertemuan penilaian yaitu pretest dan postest setiap kali pertemuan terdiri atas 2 jam pelajaran, satu jam pelajaran selama 45 menit. Adapun langkah-langkah kegiatan pembelajaran untuk kelas XI IPA 2 menggunakan model pembelajaran kooperatif tipe Jigsaw dan kelas XI IPA 3 menggunakan model pembelajaran kooperatif tipe STAD dapat dilihat pada Tabel 2.

Tabel 2. Langkah-langkah Pembelajaran Kooperatif Tipe Jigsaw dan STAD

\begin{tabular}{|c|c|}
\hline $\begin{array}{c}\text { Kelas XI IPA } 2 \text { (Pembelajaran kooperatif } \\
\text { tipe Jigsaw) }\end{array}$ & $\begin{array}{c}\text { Kelas XI IPA } 3 \text { (Pembelajaran kooperatif } \\
\text { tipe STAD) }\end{array}$ \\
\hline $\begin{array}{l}\text { Langkah I: Penyampain tujuan dan motivasi. } \\
\text { Guru menyampaikan tujuan pembelajaran } \\
\text { yang ingin dicapai dengan menggunakan } \\
\text { LCD dan memotivasi siswa untuk belajar }\end{array}$ & $\begin{array}{l}\text { Langkah I: Penyampain tujuan dan motivasi. } \\
\text { Guru menyampaikan tujuan pembelajaran } \\
\text { yang ingin dicapai dengan menggunakan } \\
\text { LCD dan memotivasi siswa untuk belajar }\end{array}$ \\
\hline Langkah II: Membentuk kelompok asal & Langkah II: Membentuk kelompok \\
\hline $\begin{array}{l}\text { Guru membentuk kelompok asal yang tediri } \\
\text { dari 4-5 siswa secara heterongen }\end{array}$ & $\begin{array}{l}\text { Guru membentuk kelompok yang tediri dari } \\
4-5 \text { siswa secara heterongen }\end{array}$ \\
\hline Langkah III: Membentuk kelompok ahli & Langkah III: Menyajikan materi pelajaran \\
\hline
\end{tabular}




\begin{tabular}{|c|c|}
\hline $\begin{array}{l}\text { Guru membentuk kelompok } \\
\text { berdasarkan tugas materi yang sama }\end{array}$ & $\begin{array}{l}\text { Guru menyajikan materi pelajaran } \\
\text { berdasarkan tujuan pembelajaran yang akan } \\
\text { dicapai dengan menggunakan media } \\
\text { pembelajaran LCD, modul siswa. }\end{array}$ \\
\hline $\begin{array}{l}\text { Langkah IV: Berdiskusi dalam kelompok } \\
\text { ahli } \\
\text { Guru membagikan modul siswa pada setiap } \\
\text { kelompok ahli dan membimbing tiap } \\
\text { kelompok ahli untuk mendiskusikan tugas } \\
\text { yang sama diberikan dan merupakan } \\
\text { tanggungjawab tiap individu, selanjutnya } \\
\text { guru mengarahkan siswa untuk kembali ke } \\
\text { kelompok asal setelah berdikusi pada tugas } \\
\text { yang sama. }\end{array}$ & $\begin{array}{l}\text { Langkah IV: Mengerjakan tugas secara } \\
\text { berkelompok } \\
\text { Guru memberikan tugas yang ada pada } \\
\text { modul siswa untuk didiskusikan dan } \\
\text { dikerjakan secara berkelompok }\end{array}$ \\
\hline Langkah V: Presentasi tiap kelompok & Langkah V: Presentasi tiap kelompok \\
\hline $\begin{array}{l}\text { Guru meminta beberapa kelompok untuk } \\
\text { mempersentasikan hasil diskusi } \\
\text { kelompoknya dan kelompok lain } \\
\text { menanggapi, guru bertindak sebagai } \\
\text { fasilitator dan memberikan penghargaan } \\
\text { kepada kelompok yang telah prenstasikan } \\
\text { hasil diskusi kelompoknya }\end{array}$ & $\begin{array}{l}\text { Guru meminta beberapa kelompok untuk } \\
\text { mempersentasikan hasil diskusi } \\
\text { kelompoknya dan kelompok lain } \\
\text { menanggapi, guru bertindak sebagai } \\
\text { fasilitator dan memberikan penghargaan } \\
\text { kepada kelompok yang telah prenstasikan } \\
\text { hasil diskusi kelompoknya }\end{array}$ \\
\hline $\begin{array}{l}\text { Langkah VI: Menyimpulkan Hasil diskusi } \\
\text { Guru mengarahkan siswa menyimpulkan } \\
\text { hasil diskusi berdasarkan tujuan yang } \\
\text { dicapai dalam pembelajaran. }\end{array}$ & $\begin{array}{l}\text { Langkah VI: Menyimpulkan Hasil diskusi } \\
\text { Guru mengarahkan siswa menyimpulkan } \\
\text { hasil diskusi berdasarkan tujuan yang dicapai } \\
\text { dalam pembelajaran. }\end{array}$ \\
\hline $\begin{array}{l}\text { Langkah VII: Evaluasi } \\
\text { Guru memberikan kuis secara tertulis untuk } \\
\text { mengetahui pemahaman siswa terhadap } \\
\text { materi yang telah didiskusikan. }\end{array}$ & $\begin{array}{l}\text { Langkah VII: Evaluasi } \\
\text { Guru memberikan kuis secara tertulis untuk } \\
\text { mengetahui pemahaman siswa terhadap } \\
\text { materi yang telah didiskusikan. }\end{array}$ \\
\hline
\end{tabular}

Teknik pengumpulan data dalam penelitian sebagai berikut: 1 . Pengumpulan data motivasi belajar menggunakan angket dibuat berdasarkan indikator motivasi belajar yang dilakukan sebelum dan sesudah penerapan model pembelajaran kooperatif tipe Jigsaw dan STAD. 2.Pengumpulan data hasil belajar dilakukan melalui pemberian tes hasil belajar dibuat berdasarkan indikator pada materi sistem koloid dilakukan sebanyak dua kali yaitu sebelum dan sesudah penerapan model pembelajaran kooperatif tipe Jigsaw dan STAD. Data yang diperoleh akan dianlisis dengan dua macam teknik analisis statistik,yaitu analisis deskriptif meliputi Analisis deskriptif untuk mengetahui tingkat motivasi belajar siswa melalui format motivasi dan tingkat penguasaan materi melalui gambaran distribusi nilai pencapaian hasil belajar siswa dengan menerapkan model pembelajaran kooperatif tipe Jigsaw dan STAD pada materi sistem koloid, dengan menggunakan SPSS 20.00 for Windows dan anlisis inferensial digunakan untuk menguji hipotesis penelitian yang telah diajukan. Analisis ini menggunakan Statistical Package For Social Science (SPSS) dengan taraf $\alpha=0,05$. Sebelum dilakukan uji hipotesis maka terlebih dahulu dilakukan uji prasyarat sebagai berikut : uji normalitas dan uji homogenitas (Sufren, 2014).

\section{HASIL DAN PEMBAHASAN}

Hasil analisis deskriptif motivasi belajar siswa kelas XI IPA 2 dan kelas XI IPA 3 di SMAN 4 Bantimurung-Maros, sebelum dan sesudah penerapan model pembelajaran kooperatif tipe Jigsaw dan STAD pada materi sistem koloid dapat dilihat pada Tabel 3. 
Tabel 3. Nilai Stasistik Deskriptif Motivasi Belajar Sebelum dan Sesudah Penerapan Model Pembelajaran Kooperatif Tipe Jigsaw dan STAD

\begin{tabular}{ccccc}
\hline \multirow{2}{*}{ Statistik } & \multicolumn{2}{c}{ Model Pembelajaran Tipe Jigsaw } & \multicolumn{2}{c}{ Model Pembelajaran Tipe STAD } \\
\cline { 2 - 5 } & Sebelum & Sesudah & Sebelum & Sesudah \\
\hline Jumlah Sampel & 35 & 35 & 35 & 35 \\
\hline Mean & 77,80 & 86,63 & 78,09 & 84,97 \\
\hline Median & 78,00 & 86,00 & 78,00 & 86,00 \\
\hline Standar Deviasi & 2,73 & 3,14 & 2,82 & 3,59 \\
\hline Varians & 7,46 & 9,89 & 7,96 & 12,91 \\
\hline Range & 12,00 & 13,00 & 12,00 & 13,00 \\
\hline Minimum & 71,00 & 80,00 & 74,00 & 77,00 \\
\hline Maksimum & 83,00 & 93,00 & 86,00 & 90,00 \\
\hline
\end{tabular}

Tabel 3 menunjukan bahwa motivasi belajar perolehan nilai siswa secarah keseluruhan dibagi dengan jumlah siswa disebut nilai ratarata sebelum dan sesudah dibelajarkan dengan model pembelajaran kooperatif tipe Jigsaw mengalami peningkatan dari 77,80 menjadi 86,63. Secara keseluruhan dari nilai perolehn siswa nilai minimum dari 71,00 menjadi 80,00 , nilai maksimum dari 83,00 menjadi 93,00, rentang atau selisih nilai maksimum dengan minimum diperoleh dari 12,00 menjadi 13,00 dan variansi atau sebaran nilai siswa yang diperoleh dari nilai standar deviasi yang dipangkatkan yang diperoleh dari 7,46 menjadi 9,89. Nilai motivasi belajar perolehan siswa secarah keseluruhan dibagi dengan jumlah siswa disebut nilai ratarata sebelum dan sesudah dibelajarkan dengan model pembelajaran kooperatif tipe STAD mengalami peningkatan nilai perolehan siswa dari 78,09 menjadi 84,97. Secara keseluruhan dari nilai perolehn siswa nilai minimum dari 74,00 menjadi 77,00 , nilai maksimum dari 86,00 menjadi 90,00, rentang atau selisih nilai maksimum dengan minimum diperoleh dari 12,00 menjadi 13,00 dan variansi atau sebaran nilai siswa yang diperoleh dari nilai standar deviasi yang dipangkatkan dari 7,96 menjadi 12,91. Hasil analisis statistik berdasarkan hasil belajar siswa kelas XI IPA-2 dan kelas XI IPA-3 di SMAN 4 Bantimurung-Maros, sebelum dan sesudah penerapan model pembelajaran kooperatif tipe Jigsaw dan STAD pada materi sistem koloid dapat dilihat pada Tabel 4.

Tabel 4. Nilai Stasistik Deskriptif Hasil Belajar Sebelum dan Sesudah Penerapan Model Pembelajaran Kooperatif Tipe Jigsaw dan STAD

\begin{tabular}{ccccc}
\hline \multirow{2}{*}{ Statistik } & \multicolumn{2}{c}{ Model pembelajaranTipe Jigsaw } & \multicolumn{2}{c}{ Model pembelajaran Tipe STAD } \\
\cline { 2 - 5 } & Sebelum & Sesudah & Sebelum & Sesudah \\
\hline Jumlah Sampel & 35 & 35 & 35 & 35 \\
\hline Mean & 61.03 & 85,60 & 60,91 & 75,09 \\
\hline Median & 60,00 & 84,00 & 60,00 & 76,00 \\
\hline Standar Deviasi & 6,16 & 4,57 & 6,37 & 5,409 \\
\hline Varians & 37,97 & 20,89 & 40,55 & 29,26 \\
\hline Range & 24,00 & 20,00 & 24,00 & 24,00 \\
\hline Minimum & 48,00 & 76,00 & 48,00 & 60,00 \\
\hline Maksimum & 72,00 & 96,00 & 72,00 & 84,00 \\
\hline
\end{tabular}

Tabel 4 menunjukkan hasil belajar siswa sebelum dibelajarkan dengan model pembelajaran kooperatif tipe Jigsaw dengan nilai perolehan nilai secarah keseluruhan dibagi dengan jumlah siswa disebut nilai rata-rata mengalami peningkatan dari 61,03 menjadi 85,60 . Secara keseluruhan dari nilai perolehan siswa nilai minimum sebelum dibelajarkan model pembelajaran kooperatif tipe Jigsaw yaitu 48,00 dan nilai maksimum 72,00. Sedangkan sesudah dibelajarkan dengan model pembelajaran kooperatif tipe Jigsaw nilai minimum 76,00 dan nilai maksimum 96,00. Rentang atau selisih nilai maksimum dengan 
minimum yaitu 24,00 menurun menjadi 20,00 dan variansi atau sebaran nilai siswa yang diperoleh dari nilai standar deviasi yang dipangkatkan dari 37,97 menurun menjadi 20,89. Hasil belajar siswa sebelum dan sesudah dibelajarkan dengan model pembelajaran kooperatif tipe STAD perolehan nilai siswa secarah keseluruhan dibagi dengan jumlah siswa disebut nilai rata-rata yang mengalami peningkatan dari 60,91 menjadi 75,09. Secara keseluruhan nilai minimum sebelum dan sesudah dibelajarkan model pembelajaran kooperatif tipe STAD dari 48,00 menjadi 60,00 , dan nilai maksimum dari 72,00 menjadi 84,00. Rentang atau selisih nilai maksimum dengan minimum sebelum dan sesudah penerapan model pembelajaran kooperatif tipe STAD yaitu 24,00 dan variansi atau sebaran nilai siswa yang diperoleh dari nilai standar deviasi yang dipangkatkan dari 40,55 menurun menjadi 29,26.

Tabel 5. Rata-rata Nilai N-Gain Hasil Belajar Siswa Pada Model Pembelajarn Kooperatif Tipe Jigsaw dan STAD

\begin{tabular}{ccc}
\hline Pembelajaran kooperatif & Rata-rata N-Gain & Kategori \\
\hline Model tipe Jigsaw & 0,63 & Sedang \\
\hline Model tipe STAD & 0,35 & Sedang \\
\hline
\end{tabular}

Tabel 5. menunjukkan nilai rata-rata $\mathrm{N}$ Gain hasil belajar siswa pada model pembelajaran kooperatif tipe Jigsaw sebesar 0,63 dengan kategori sedang dan model pembelajaran kooperatif tipe STAD sebesar 0,35 dengan kategori sedang.

Uji normalitas digunakan untuk mengetahui apakah data sampel yang diteliti berasal dari populasi yang terdistribusi normal. Pengujian normalitas data motivasi dan hasil belajar siswa dihitung dengan program SPSS 20 for windows menggunakan analisis One-SampleKolmogorov-Smirnov Test. Kriteria pengujiannya adalah data memiliki sebaran distribusi normal jika angka signifikansi $(p)$ yang diperoleh lebih besar dari $\alpha=0,005$. Apabila nilai signifikan $(p)$ yang diperoleh lebih kecil dari $\alpha$ $=0,005$ maka data berasal dari populasi yang tidak terdistribusi normal. Hasil pengujian normalitas data motivasi belajar dan hasil belajar siswa disajikan pada Tabel 5.

Tabel 6 Hasil Uji Normalitas Data Motivasi dan Hasil Belajar Pada Model Pembelajaran Kooperatif Tipe Jigsaw dan STAD

\begin{tabular}{ccc}
\hline & Motivasi Belajar & Hasil Belajar \\
\hline $\mathrm{N}$ & 35 & 35 \\
\hline Nilai Signifikansi & .200 & .083 \\
\hline
\end{tabular}

Tabel 6 menyatakan bahwa nilai signifikansi yang diperoleh dari data motivasi belajar yang diperoleh adalah $0,200>0,05$ dan data hasil belajar yang diperoleh adalah $0,083>$ 0,05 , maka data motivasi dan hasil belajar berasal dari populasi yang terdistibusi normal.Uji homongentas digunakan untuk mengetahui apakah kedua sampel berasal dari populasi yang memiliki varians yang sama (homogen). Pengujian homogenitas motivasi dan hasil belajar dihitung dengan bantuan SPSS 20 for windows menggunakan analisis Levenes's Test of Equality Of Eror Variance. Kriteria pengujian yaitu data berasal dari populasi yang sama (homongen) jika nilai signifikansi $(p)>0,05$. Hasil analisis uji homogenitas data motivasi dan hasil belajar pada pembelajaran kooperatif tipe Jigsaw dan STAD disajikan pada Tabel 6

Tabel 7. Hasil Uji Homogenitas Data Motivasi dan Hasil Belajar Pada Model Pembelajaran Kooperatif Tipe Jigsaw dan STAD

\begin{tabular}{cccc}
\hline & F & df & Sig \\
\hline Motivasi Belajar & .331 & 68 & .567 \\
\hline Hasil Belajar & 1.249 & 68 & .268 \\
\hline
\end{tabular}


Tabel 7 menyatakan bahwa nilai signifikansi yang diperoleh dari data morivasi belajar yang diperoleh $0,567>0,05$ dan data hasil belajar yang diperoleh $0,268>0,05$ maka data motivasi dan hasil belajar berasal dari populasi yang memiliki varians yang sama (homongen). Hasil analisis pengujian hipotesis dengan analisis Independen Samples Test disajikan dalam Tabel 7.

Tabel 8. Hasil Analisis Pengujian Hipotesis I dan II

\begin{tabular}{cccc}
\hline & $\mathrm{t}$ & $\mathrm{df}$ & $\mathrm{Sig}$ \\
\hline Motivasi Belajar & 3.371 & 68 & .001 \\
\hline Hasil Belajar & 9.571 & 68 & .000 \\
\hline
\end{tabular}

Uji hipotesis I rumusan hipotesisnya yaitu ada pengaruh model pembelajaran kooperatif tehadap motivasi belajar dengan menggunakan model pemebealajaran kooperatif tipe Jigsaw dan STAD pada materi sistem koloid kelas XI IPA SMAN 4 Bantimurung. Hipotesis statistiknya sebagai berikut :

$$
\begin{aligned}
& \mathrm{H}_{0}: \mathrm{A}_{1}=\mathrm{A}_{2} \\
& \mathrm{H}_{1}: \mathrm{A}_{1} \neq \mathrm{A}_{2}
\end{aligned}
$$

Kriteria pengujian yaitu $p \geq \alpha(0,05)$ maka harga $\mathrm{H}_{0}$ diterima sedangkan jika $\mathrm{p}<\alpha$ $(0,05)$ maka $\mathrm{H}_{0}$ ditolak. Berdasarkan hasil analisis pada Tabel 7 diperoleh nilai signifikansi $0,001<0,05$ maka $\mathrm{H}_{0}$ ditolak dan $\mathrm{H}_{1}$ diterima artinya ada pengaruh model pembelajaran kooperatif tehadap motivasi belajar siswa dengan menggunakan model pemebealajaran kooperatif tipe Jigsaw dan STAD pada materi sistem koloid kelas XI IPA SMAN 4 Bantimurung-Maros. Uji hipotesis II rumusan hipotesisnya yaitu ada pengaruh model pembelajaran kooperatif tehadap hasil belajar dengan menggunakan model pemebealajaran kooperatif tipe Jigsaw dan

Tabel 9 Hasil Analisis Hubungan Motivasi Dengan Hasil Belajar Pada Model Pembelajaran Koopeatif Tipe Jigsaw dan STAD

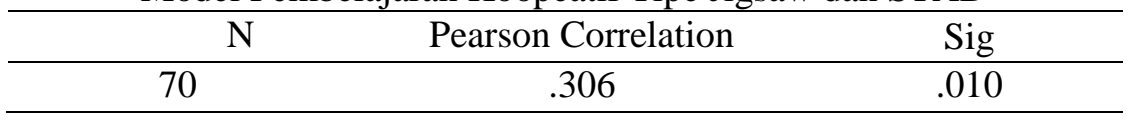

Tabel 8 menunjukkan jumlah sampel $(N)$ yang digunakan sebanyak 70 siswa. Nilai korelasi $(r)$ terhadap hubungan antara motivasi dengan hasil belajar siswa menghasilkan nilai koefisien korelasi sebesar 0,306 dengan kategori tingkat hubungan lemah, nilai signifikansi yang diperoleh dari data hubungan motivasi dengan hasil belajar adalah $0,010<0,05$ maka $\mathrm{H}_{0}$ ditolak dan $\mathrm{H}_{1}$ diterima artinya ada hubungan signifikansi antara motivasi dengan hasil belajar siswa yang dibelajarkan dengan model kooperatif tipe Jigsaw dan STAD pada materi sistem koloid
STAD pada materi sistem koloid kelas XI IPA SMAN 4 Bantimurung-Maros.

Hipotesis statistiknya sebagai berikut :

$$
\begin{aligned}
& \mathrm{H}_{0}: \mathrm{B}_{1}=\mathrm{B}_{2} \\
& \mathrm{H}_{1}: \mathrm{B}_{1} \neq \mathrm{B}_{2}
\end{aligned}
$$

Kriteria pengujian yaitu $\mathrm{p} \geq \alpha(0,05)$ maka harga $\mathrm{H}_{0}$ diterima sedangkan jika $\mathrm{p}<\alpha$ $(0,05)$ maka $\mathrm{H}_{0}$ ditolak. Berdasarkan hasil analisis pada Tabel 7 diperoleh nilai signifikansi $0,000<0,05$ maka $\mathrm{H}_{0}$ ditolak dan $\mathrm{H}_{1}$ diterima artinya ada pengaruh model pembelajaran kooperatif tehadap hasil belajar dengan menggunakan model pemebealajaran kooperatif tipe Jigsaw dan STAD pada materi sistem koloid kelas XI IPA SMAN 4 BantimurungiMaros. Uji hipotesis III interprestasi koefisien hubungan motivasi dengan hasil belajar siswa setelah dibelajarkan dengan model pembelajaran kooperatif tipe Jigsaw dan tipe STAD disajikan pada Tabel 9 .

siswa kelas XI IPA SMAN 4 BantimurungMaros. Nilai korealsi $(r)$ di dapat antara motivasi dengan hasil belajar adalah 0,306. Hal ini menunjukkan bahwa terjadi hubungan yang lemah antara motivasi dengan hasil belajar. Sedangkan arah hubungannya adalah positif karena nilai korelasi positif.

\subsection{Pembahasan}

Berdasarkan hasil analisis deskriptif data menunjukkan nilai rata-rata motivasi belajar siswa kelas XI IPA 2 yang dibelajarkan dengan 
model kooperatif tipe Jigsaw mengalami peningkatan, sebelum penerapan model kooperatif tipe Jigsaw yaitu 77,80 sesudah penerapan model menjadi 86,63 . Nilai rata-rata motivasi belajar siswa kelas XI IPA 3 yang dibelajarkan dengan model kooperatif tipe STAD mengalami peningkatan, sebelum penerapan model kooperatif tipe STAD yaitu 78,09 sesudah penerapan model menjadi 84,97 . Nilai rata-rata motivasi belajar siswa penerapan model pembelajaran kooperatif tipe Jigsaw lebih tinggi daripada nilai rata-rata perolehan penerapan model pembelajaran kooperatif tipe STAD, hal ini disebabkan karena pada pembelajaran kooeperatif tipe Jigsaw siswa lebih termotivasi mengikuti pembelajaran karena setiap siswa dalam kelompok bertanggung jawab mempelajari materi tertentu yang ditugaskan dan bertanggung jawab terhadap kelompoknya, didalam kelompoknya siswa juga sebagai tutor sebaya. Dalam penerapan model pembelajaran kooperatif tipe Jigsaw guru hanya mengarahkan siswa dan menfasilitasi, menilai dalam kegiatan pembelajaran. Hal ini sejalan dengan hasil penelitian Erikson ( 2015 ) menunjukkan siswa termotivasi tinggi dengan model pembelajaran koperatif tipe Jigsaw daripada pembelajaran secara langsung. Hasil analisis deskriptif data menunjukkan nilai rata-rata hasil belajar siswa kelas XI IPA 2 yang dibelajarkan dengan model kooperatif tipe Jigsaw mengalami peningkatan, sebelum penerapan model kooperatif tipe Jigsaw yaitu 61,03 sesudah penerapan model menjadi 85,60 . Nilai rata-rata hasil belajar siswa kelas XI IPA 3 yang dibelajarkan dengan model kooperatif tipe STAD juga mengalami peningkatan, sebelum penerapan model pembelajaran kooperatif tipe STAD yaitu 60,91 sesudah penerapan model menjadi 75,09. Natarata nilai $\mathrm{N}$-Gain yaitu 0,35 dengan kategori sedang. Berdasarkan nilai rata-rata $\mathrm{N}-\mathrm{Gain}$ kelas XI IPA 2 yang dibelajarkan dengan model pembelajaran kooperatif tipe Jigsaw lebih tinggi dibandingkan dengan kelas XI IPA 3 yang dibelajarkan dengan model pembelajaran kooperatif tipe STAD. Hal ini disebabkan pada pembelajaran kooperatif tipe Jigsaw siswa bertanggung jawab terhadap materi pelajaran yang ditugaskan terhadap pembelajarannya sendiri dan juga pembelajaran siswa lain, tidak hanya mempelajari materi yang diberikan, tetapi juga harus dan mengajarkan materi tersebut kepada siswa lain dalam kelompoknya. Siswa bertindak sebagai tutor sebaya dalam kelompoknya dapat meningkatkan kognitif, sehingga memperoleh hasil belajar yang maksimum terhadap materi sistem koloid yang terdiri dari konsep-konsep yang kongkrit serta fenomena-fenomena yang terjadi di alam. Hal ini sejalan dengan hasil penelitian Fadlyani (2014), penerapan pembelajaran kooperatif tipe Jigsaw meningkatkan hasil belajar siswa dibandingkan pemebelajaran secara konvensional.

Berdasarkan analisis inferensial data Tabel 7 diperoleh pada pengujian hipotesis I

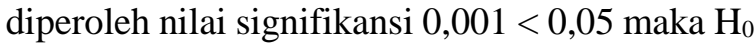
ditolak dan $\mathrm{H}_{1}$ diterima artinya ada pengaruh model pembelajaran kooperatif tipe Jigsaw dan STAD tehadap motivasi belajar pada materi sistem koloid kelas XI IPA SMAN 4 Bantimurung-Maros. Penerapan model pembelajaran kooperatif tipe Jigsaw dan STAD dapat mempengaruhi motivasi belajar, pada model pemebelajaran kooperatif siswa bekerja sama dan bertanggung jawab dalam menyelesaian tugas baik secara mandiri maupun secara berkelompok. Dengan bekerja sama dalam kegiatan pembelajaran siswa akan lebih termotivasi dalam memahami materi pelajaran, pada materi sistem koloid yang teridiri dari konsep-konsep dan fenomena alam yang terjadi membuat siswa akan aktif dalam kegiatan pemebelajaran karena siswa lebih dominan dalam kegiatan pembelajaran seperti diskusi antar kelompok maupun dalam kelompoknya. Berdasarkan analisis inferensial data Tabel 7 hasil pengujian hipotesis II diperoleh nilai signifikansi $0,000<0,05$ maka $\mathrm{H}_{0}$ ditolak dan $\mathrm{H}_{1}$ diterima artinya ada pengaruh model pembelajaran kooperatif tipe Jigsaw dan STAD tehadap hasil belajar siswa pada materi sistem koloid kelas XI IPA SMAN 4 BantimurungMaros. Penerapan model pemebelajaran kooperatif tipe Jigsaw dan STAD dapat mempengaruhi hasil belajar, karena pada model pemebelajaran kooperatif tipe Jigsaw dan STAD mengutamakan keaktifan siswa dalam kegiatan pemebelajaran karena dalam kelompok terdiri dari siswa yang heterongen, untuk menyelesaikan tugas siswa baik secara berkelompok maupun secara individu, siswa saling berdiskusi, ada yang bertindak sebagai tutor sebaya sehingga pengetahuan dan pemahaman siswa lebih mendalam pada materi yang sedang dibahas atau didiskusikan. Pada materi sistem koloid terdiri dari konsep-konsep dan fenomena alam yang terjadi dalam kehidupan sehari-hari membuat siswa mudah memahami materi pelajaran jika 
dilakukan dengan cara berdiskusi lebih meningkatkan pengetahuan dan pemahaman membuat hasil belajar siswa meningkat.

Berdasarkan analisis inferensial dari Tabel 8 diperoleh hasil pengujian hipotesis III

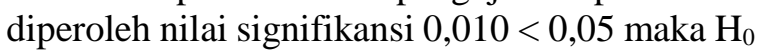
ditolak dan $\mathrm{H}_{1}$ diterima artinya ada hubungan signifikansi antara motivasi dengan hasil belajar pada penerapan model pebelajaran kooperatif tipe Jigsaw dan STAD pada materi sistem koloid kelas XI IPA SMAN 4 Bantimurung-Maros. Hubungan antara motivasi denagn hasil belajar siswa pada penerapan model pemebelajaran kooperatif tipe Jigsaw dan STAD, perolehan nilai koefisien korelasi $(r)$ sebesar 0,306 dengan kategori lemah artinya terdapat hubungan yang lemah antara motivasi dengan hasil belajar siswa kelas XI IPA SMAN 4 Bantimurung Maros pada materi sistem koloid sesudah dibelajarkan dengan menggunakan model pemebelajaran kooperatif tipe Jigsaw dan STAD, berarti semakin rendah motivasi belajar maka semakin rendah juga nilai hasil belajar. Sedangkan arah hubungan adalah positif karena nilai keoefisien korelasi $(r)$ positif, nilai tersebut menunjukkan bahwa terdapat pengaruh positif antara motivasi dan hasil belajar siswa. Hal ini sejalan dengan hasil penelitian Nurmiati (2013) menyimpulkan bahwa motivasi belajar dengan hasil belajar siswa berhubungan positif dengan nilai koefisien korelasi sebesar 0,208 dengan kategori lemah pada mata pelajaran biologi siswa SMAN di kota Makassar.

\section{SIMPULAN DAN SARAN}

Berdasarkan hasil analisis data dan pembahasan dapat disimpulkan bahwa: (1) ada pengaruh model pembelajaran kooperatif terhadap motivasi belajar siswa pada materi sistem koloid kelas XI IPA SMAN 4 Bantimurung-Maros.(2) ada pengaruh model pembelajaran kooperatif terhadap hasil belajar siswa pada materi sistem koloid kelas XI IPA SMAN 4 Bantimurung-Maros.(3) hubungan motivasi dengan hasil belajar siswa menghasilkan koefisien korelasi sebesar 0,306 dengan kategori lemah, yang artinya bahwa motivasi belajar berhubungan positif dan nilai signifikansi adalah $0,010<0,05$ maka $\mathrm{H}_{0}$ ditolak dan $\mathrm{H}_{1}$ diterima , artinya bahwa ada hubungan signifikansi antara motivasi dengan hasil belajar siswa pada materi sistem koloid penerapan model pembelajaran kooperatif kelas XI IPA SMAN 4 Bantimurung-Maros. Berdasarkan hasil yang diperoleh dari penelitian ini, maka dikemukakan saran-saran sebagai berikut : (1) kepada guru mata pelajaran kimia, khususnya di SMAN 4 Bantimurung-Maros disarankan agar menerapkan model pembelajaran kooperatif tipe Jigsaw atau STAD, untuk materi sistem koloid karena dapat meningkatkan motivasi dan hasil belajar siswa.

(2) diharapakan kepada peneliti selanjutnya untuk mengembangkan penelitian ini dengan menggunakan model pembelajaran kooperatif yang lain dengan kurikulum tahun 2013.

\section{DAFTAR RUJUKAN}

Anni. 2004. Psikologi Belajar. Semarang: UPT MKK UNNES

Departemen Pendidikan Nasional. 2012. Direktorat Jenderal Manajemen Pendidikan Dasar dan

Menengah. Direktorat Pembinaan Sekolah

Depdiknas. 2006. Silabus Mata Pelajaran Kimia. Jakarta: Departemen Pendidikan Nasional.

Erikson.S. 2015. Pengaruh Model Pembelajaran Kooperatif dan Motivasi Belajar terhadap

Hasil Belajar Bahasa Indonesia Siswa Kelas VIII Sekolah Menengah Pertama Katolik

Santa Maria Medan. Tesis Tidak Diterbitkan. Medan. Universitas Negeri Medan.

Fadlyani. 2014. Pembelajaran Kooperatif Sistem Tipe Jigsaw Pada Konsep

Pencernaan Makanan Manusia Terhadap Hasil Belajar Siswa SMAN 1 Sakti Kabupaten Pidie. Banda Aceh: Jurnal Biotik, 2 (1), 1-76

Gunarsa. S.D. 2004. Psikologi Keperawatan. Jakarta: PP BPK Gunung Mulia.

Lie. 2004. Cooperatif Learning: Mempraktekkan Cooperatif Learnig di Ruang-ruang Kelas.

Jakarta: Raja Widia Sarana Indonesia

Nurhadi. 2004. Kurikulum 2004 (Pertanyaan dan Jawaban). Jakarta: Grasindo

Nurmiati. 2013. Hubungan Antara Cara Belajar dan Motivasi Belajar Siswa Dengan Hasil 
Belajar Biologi siswa SMA di Kota Makassar.

Tesis, Tidak diterbitkan. Jurusan

Biologi. Makassar: FMIPA UNM.

Rusman. 2010. Model-model Pembelajaran dan

Mengembangkan Profesionalisme

Guru. Jakarta:

PT. Raja Grafindo Persada

Rukminto, I.A., 1994. Psikologi dan Ilmu Kesejahteraan Sosial. Jakarta: Grafindo Persada.

Sanjaya,W. 2013. Strategi Pembelajaran Berorientasi Standar Proses Pendidikan. Jakarta:

Prenadamedia Group

Sardiaman. 2014. Interaksi dan Motivasi Belajar Mengajar. Jakarta: Raja Grafindo.

Slavin. 2010. Cooperative Learning: Teori, Riset, and Praktik (Terjemahan dari Cooperative

Sudjana. 1996. Cara Belajar Siswa Aktif dalam Proses Belajar Mengajar. Bandung: Sinar Baru

Algensindo

Sufren. 2014. Belajar Otodidak SPSS Pasti Bisa. Jakarta.Elex Media Komputindo

Gramedia Kompas

Sugiyono. 2013. Metode Penelitian Pendidikan Pendekatan Kuantitatif, Kualitattif, dan

R\&D.Bandung: Alfabeta.

Suprapto. 2015. Pengaruh Model Pembelajaran Kooperatif Tipe STAD Terhadap Peningkatan
Kemampuan Representasi dan Pemecahan Masalah Matematis Peserta Didik. Lampung:

Journal of Mathematics and Education, 2 (3)

Suprijono. 2013. Cooperatif Learning. Yogyakarta: Pustaka Belajar

Susanto. 2013. Teori Belajar dan Pembelajaran di Sekolah Dasar. Jakarta: Kencana.

Trianto. 2007. Model-Model Pembelajaran Inovatif Berorientasi Konstruktivistik. Jakarta:

Prestasi Pustaka.

Trianto. 2010. Mendesain Model Pembelajaran Inovatif Progresif. Jakarta: Kencana

Uno,H. 2016. Teori Motivasi dan Pengukurannya. Jakarta: Bumi Aksara. 